\title{
Correction to: Design of new resource allocation scheme for symbiosis of DASH clients and non-DASH clients
}

Hyun Jun $\mathrm{Kim}^{\dagger}{ }^{\mathbb{D}}$, Ye Seul Son ${ }^{\dagger}$ and Joon Tae Kim

The original article can be found online at https://doi. org/10.1186/s13638-018 1228-9.

*Correspondence: jtkim@konkuk.ac.kr ${ }^{\dagger}$ Hyun Jun Kim and Ye Seul Son equally contributed to this work

Department of Electronic Engineering, Konkuk

University, Seoul, Republic of Korea

\section{Corrections to: EURASIP Journal on Wireless Communications and Networking} (2018) 2018:229 https://doi.org/10.1186/s13638-018-1228-9

Following publication of the original article [1], it was brought to the authors' attention that the corresponding authorship had been incorrectly assigned.

Namely, the third author, Joon Tae Kim, should be the corresponding author (not the first, to whom the corresponding authorship was originally assigned).

The corresponding authorship has since been corrected in the original article and can be found in this correction.

The authors apologize for any inconvenience caused.

Published online: 09 February 2021

Reference

1. H.J. Kim, Y.S. Son, J.T. Kim, Design of a new resource allocation scheme for symbiosis of DASH clients and non-DASH clients. Eurasip J. Wirel. Commun. Netw. (2018). https://doi.org/10.1186/s13638-018-1228-9

\section{Publisher's Note}

Springer Nature remains neutral with regard to jurisdictional claims in published maps and institutional affiliations. author(s) and the source, provide a link to the Creative Commons licence, and indicate if changes were made. The images or other third party material in this article are included in the article's Creative Commons licence, unless indicated otherwise in a credit line to the material. If material is not included in the article's Creative Commons licence and your intended use is not permitted by statutory regulation or exceeds the permitted use, you will need to obtain permission directly from the copyright holder. To view a copy of this licence, visit http:// creativecommons.org/licenses/by/4.0/. 